\title{
IMPACT OF SELF HELP GROUPS IN WOMEN'S OVERALL DECISION MAKING
}

\author{
Dipika Mallick \\ Asian Institute of Public Health, Odisha, India \\ Indurani Sagar \\ Research Assistant, IIPH, Bhubaneswar, Odisha \\ Kripalini Patel \\ SRF, ICMR-RMRC, Bhubaneswar, Odisha
}

Chandni Shrivastava

State consultant RKSK, NHM, Raipur, Chhattisgarh, India

Henanee Anand

Research Assistant - OSSRC, Odisha, India

Bijayalaxmi Sahoo

Assistant Professor, Utkal University, Odisha, India

Sunita Jena

Research Officer, AIIMS, Bhubaneswar, India

\begin{abstract}
Self Help Group (SHG) is a voluntary small group of Individuals in an area specifically from the same socio-economic background. SHG improve the efforts of women in respect of Investment, Production \& Marketing which create a major tool in empowering women and promoting micro-finance in society. A Community based cross sectional study was conducted in Balipatna Block. Out of 129 functioning SHG's, 10 groups was selected by simple random method and those who agreed to participate in the interview by using a pre-validated questionnaire. Data was entered in Epiinfo (version 3.5.1) statistical software package then exported to SPSS software package version $\mathbf{1 6 . 0}$ for further analysis. A total of 186 SHG members were included in this study. The majority of participants were between age group 20-40 years. Most of them were having secondary level of education or primary level. A large chunk of participant were married $(\mathbf{8 7 \%})$ and living in a joint family $\mathbf{( 7 8 \% )}$. Majority were doing animal husbandry (27\%) and housewives (26\%). In our study 69\% of SHGs availed loan of amount more than 10000, and the prime motive of functioning of SHGs were to develop savings (61\%) and Period of Functioning of SHG was one to three year $(53 \%)$. Frequency of Group Meeting for $71 \%$ SHGs was monthly and half of the SHGs save 100-500 per meeting. The decision makers in utilizing loan amount is manly spouse $(53 \%)$, very few decides by all $(21 \%)$, themselves $(18 \%)$ and by family $(8 \%)$. The analyzed findings proved that there is a huge
\end{abstract}

positive impact of SHGs on women empowerment in study area of Odisha in terms of increase in savings habits, profits level, self service, asset creation, social consciousness and participation, reimbursement of other debts, improvement in choice making skills.

Key Words: Self Help Group (SHG), Microfinance, Assessment, Poverty, and Women Empowerment

\section{INTRODUCTION}

Micro Finance is emerging as a powerful instrument for poverty alleviation in India and one such group for providing microfinance is Self Help Groups (SHG) (1).SHG is a voluntary small group of Individuals in an area specifically from the same socio-economic background and it plays an important role in reducing poverty (5). SHGs aimed at providing a cost effective mechanism for providing financial services to the poor people (1) and to have active participation in the society (2). SHG improve the efforts of women in respect of investment, production \&marketing which create a major tool in empowering women and promoting microfinance in society (6). SHG helps women to achieve a general goal and also to achieve the strength to fight against exploitation which they are facing in numerous categories such as (7) economic, legal, health, and cultural objectives (8). 
As various significant factors such as class, caste, culture and patriarchy systems are embedded at the societal level, for which women are being discriminated and exploited. Also, few studies have revealed that, the subordinate position of the women is perfection and reinforced by their limited access to control over resources (3). "Women empowerment" is a mantra of the new millennium, which help the nation for a better development; "When women move forward, the family moves, the village moves". Therefore, the need to empower women arises in the third world developing countries at global level (4). Furthermore, the concept of women empowerment also facilitate women to have a better control over their household resources, definitive decision making power and ability to participate in public speaking (8). However, in this generation, women empowerment means to gain an independent social status and a viable financial option and cultural support in the society, a women can have the power to improve (9).

Several studies have been conducted in India in this context among which, a study revealed the purposes to join in SHG to avail of credit, promote saving, avail benefits from NonGovernmental Organization (NGOs) and government and develop awareness (10). A research articled entitled "Role of micro finance in women empowerment in India ${ }^{e e}$ stated that micro finance scene is dominated by self-help groups as a mechanism for providing financial help to the poor and it concluded that the aim of micro finance is to empower women who traditionally lack of access to banking and related financial services (11). Sahu Lopamudra and Singh Suresh K (2012) assessed the role of SHG in empowerment of women and the key responses of the study were increased participation in household decision making, gaining respect in family, increased savings, meeting family expenses, improved political knowledge, independence, confidence etc. The evidence also shows of gaining respect and trust in society and were able to plan for the future of their families(12).

Studies have shown that the participation of women in SHGs made a significant impact on their empowerment both in social and economic aspects (13). It has also found that social backwardness, indebtedness and presence of other microcredit programmes in the same or nearby villages have a significant positive influence on women's participation in this programme (14). Recent evidence from Bolivia shows that the intent and social perspectives of the lender, which are often captured in the credit-plus approach, can be an important factor affecting the achievement of economic and gender empowerment through micro-finance (15). SHG has led to boost the process of women's Empowerment. Yet women are subservient to men as they are subject to many socioeconomic and cultural constraints. The situation is more severe in the rural and backward areas. Women development activities must be given importance to eradicate poverty, increase the economic growth and for better standard of living. The SHG promotes small savings among members. However in Odisha few studies have conducted related to SHGs group and its empowerment so this study aimed to find out the role of SHG in developing socio economic status of rural women, to know how much SHGs involved in alleviation of the rural poverty and increase employment opportunity and to evaluate the income generating activities in rural household women

\section{METHOD}

A Community based cross-sectional study was conducted in Balipatna Block of Odisha, India. Out of 129 functioning SHG's, 10 groups were selected by simple random method and those who agreed to participate was interviewed by using a prevalidated questionnaire. The populations included under study included were the members of self-help group. The questionnaire was compiled following a comprehensive literature review and consisted of closed ended questions. Closed-ended questions offer interviewer a number of alternative responses from which they have to choose the one. The questionnaires were pre-tested and reviewed to ascertain the suitability of the tool before the actual administration. Pre-testing was done by administering the questionnaire to other women. SHGs of other block selected randomly to represent $10 \%$ of the actual population recommended for pre testing the questionnaire to ensure validity.

The findings were used to improve the questionnaire to ensure validity and reliability. This information did not form part of the study data. Data was collected for 4 weeks from December 2016 - February 2017. The questionnaires were asked at the time of data collection, an appointment was made, and respondents were notified of the date and time of data collection by their leaders. During the data collection periods, in order to obtain informed consent, the researcher visited the SHG women, and explained the nature and aim of the study to the individual respondents and what was expected from them. The interviewer personally asked all the questions and answers were given on researcher's presence to enable him to clarify any questions that might arise, and to ensure that respondents answered the questionnaire themselves and that all the questionnaires were returned. Respondents were informed that participation in the study was voluntary and that they could withdraw from the study at any stage if they so wished. Each of the study participants were assured by the authors that the study findings would not have any impact on their day today's life.

After completion, the questionnaires were collected by the principal researcher and by the research assistants. The questionnaire was verified for accuracy and completeness. Data from properly completed questionnaire was entered into Epi-info (version 3.5.1) statistical software package then exported to SPSS software package version 16.0 for further analysis. The data was analyzed, and results presented under each specific objective in order to effectively answer the research questions. Coding was used to ensure accuracy during data analysis. Quantitative data was analyzed using descriptive and inferential statistics. 


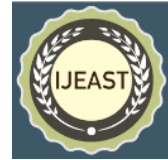

\section{RESULTS}

The totals of 186 participants were interviewed with questioner designed for this study. In presenting the data displayed in Tables I, we begin by highlighting the characteristics of our study participant i.e self-help group members. The majority of participants were between age group 20-40 yr. approximately 37 percent were having secondary level of education followed by primary level (32\%), higher secondary level (13\%) illiterate $(12 \%)$ and graduation $(1 \%)$. Most of the participant were married $(87 \%)$ and living in a joint family (78\%). Principally most of them were having 4-8 members in their family (64\%) and only one earning member for the family (49\%). With respect to occupation, majority were doing animal husbandry $(27 \%)$, followed by housewives $(26 \%)$, agriculture labor (23\%), Non-Agricultural Labor (15.05\%), Employed $(6 \%)$ and others $(2 \%)$. While $80 \%$ of participants were living in their own house and $58 \%$ were not the owner of any agricultural land.

Table 1: Socio-demographic Profile of SHGs Members (N=186)

\begin{tabular}{|c|c|c|c|}
\hline \multicolumn{2}{|l|}{ Variables } & Frequenc & Percentage \\
\hline \multirow{3}{*}{ Age } & $>20$ Year & 9 & 4.84 \\
\hline & 20-40 Years & 155 & 82.79 \\
\hline & Above 40 Years & 22 & 11.83 \\
\hline \multirow[t]{5}{*}{ Education } & Illiterate & 29 & 15.60 \\
\hline & Primary & 61 & 32.80 \\
\hline & Secondary & 70 & 37.63 \\
\hline & Higher Secondary & 24 & 12.90 \\
\hline & Graduation & 2 & 1.07 \\
\hline \multirow[t]{3}{*}{ Marital Status } & Unmarried & 7 & 3.76 \\
\hline & Married & 161 & 86.55 \\
\hline & Widow/Divorced & 18 & 9.68 \\
\hline \multirow[t]{2}{*}{ Type of Family } & Nuclear & 41 & 22.04 \\
\hline & Joint & 145 & 77.95 \\
\hline \multirow[t]{3}{*}{ Family Size } & Less than 4 & 41 & 22.04 \\
\hline & 4- 8 & 119 & 63.98 \\
\hline & Above 8 & 26 & 13.98 \\
\hline \multirow{4}{*}{$\begin{array}{l}\text { Number of Income } \\
\text { Earners In Family }\end{array}$} & One & 91 & 48.92 \\
\hline & Two & 44 & 23.65 \\
\hline & Three & 30 & 16.12 \\
\hline & More than Three & 21 & 11.29 \\
\hline \multirow[t]{6}{*}{ Occupation } & Agricultural Labor & 42 & 22.58 \\
\hline & $\begin{array}{l}\text { Non Agricultural } \\
\text { Labor }\end{array}$ & 28 & 15.05 \\
\hline & Animal Husbandry & 51 & 27.41 \\
\hline & Employed & 12 & 6.45 \\
\hline & Housewife & 50 & 26.88 \\
\hline & Others & 3 & 1.61 \\
\hline \multirow{2}{*}{$\begin{array}{l}\text { Agricultural Land } \\
\text { Dwner }\end{array}$} & Yes & 79 & 42.47 \\
\hline & No & 107 & 57.53 \\
\hline \multirow[t]{2}{*}{ Possession of House } & Own & 149 & 80.10 \\
\hline & Rented & 37 & 19.90 \\
\hline
\end{tabular}

Figure no 1 shows the Loan Amount Availed by SHGs, our study $69 \%$ of SHGs availed loan of amount more than 10000 , in comparison of that $18 \%$ availed loan for amount between 3000 10000 and only $13 \%$ availed load of budget less than 3000 .

\section{Loan Amount Availed by SHGs}

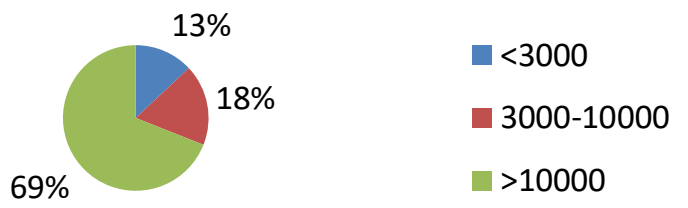

Figure 1: Loan amount the participants

Data showed in table number 2 can be concluded as the Prime Motive of functioning of SHGs was to develop savings $(61 \%)$ and Period of Functioning of SHG was one to three year $(53 \%)$. Frequency of Group Meeting for $71 \%$ SHGs was monthly and half of the SHGs save 100-500 per meeting. Each SHG have Credit Facilities Availed after Joining Self Help Group (SHG).

Table 2: Characteristics and Functioning of SHGs

\begin{tabular}{|c|c|c|c|}
\hline \multicolumn{2}{|l|}{ Categories } & Frequency & Percentage \\
\hline \multirow[t]{4}{*}{ Prime Motive } & To develop saving & 114 & 61.30 \\
\hline & $\begin{array}{l}\text { To get access to credit } \\
\text { acilities }\end{array}$ & 33 & 17.74 \\
\hline & $\begin{array}{l}\text { For achieving economic } \\
\text { elf-reliance }\end{array}$ & 17 & 9.14 \\
\hline & \begin{tabular}{|l|} 
For Socio political \\
mpowerment and \\
ustenance
\end{tabular} & 22 & 11.82 \\
\hline \multirow{3}{*}{\begin{tabular}{|l} 
Period of \\
Functioning of SHG
\end{tabular}} & Less than one year & 19 & 10.21 \\
\hline & One to three years & 98 & 52.68 \\
\hline & More than 3 years & 69 & 37.09 \\
\hline \multirow{3}{*}{$\begin{array}{l}\text { Frequency of Grour } \\
\text { Meeting }\end{array}$} & Weekly Once & 41 & 22.04 \\
\hline & Fortnight once & 12 & 6.45 \\
\hline & Monthly once & 133 & 71.50 \\
\hline \multirow{3}{*}{$\begin{array}{l}\text { Saving Amount per } \\
\text { Meeting }\end{array}$} & Less than $100 \mathrm{Rs}$ & 71 & 38.17 \\
\hline & $100-500 \mathrm{Rs}$ & 93 & 50 \\
\hline & More than $500 \mathrm{Rs}$ & 22 & 11.82 \\
\hline \multirow{2}{*}{$\begin{array}{l}\text { redit Facilities } \\
\text { Availed After Joining } \\
\text { Self Help Group } \\
\text { SHG) }\end{array}$} & Yes & 186 & 100 \\
\hline & No & 0 & 0 \\
\hline \multirow{4}{*}{$\begin{array}{l}\text { Impact of Joining } \\
\text { Self Help Group }\end{array}$} & Rise in Income & 84 & 45.16 \\
\hline & Education of Dependent & 26 & 13.98 \\
\hline & $\begin{array}{l}\text { Improved Nutrition in } \\
\text { Household }\end{array}$ & 9 & 4.84 \\
\hline & $\begin{array}{l}\text { Social Awareness or } \\
\text { Participation }\end{array}$ & 33 & 17.74 \\
\hline
\end{tabular}




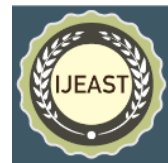

\begin{tabular}{|l|l|l|l|}
\hline \multirow{1}{*}{} & Self-Employment & 14 & 7.53 \\
\cline { 2 - 4 } $\begin{array}{l}\text { Political Awareness or } \\
\text { Zarticipation }\end{array}$ & 16 & 8.60 \\
\cline { 2 - 4 } & Others & 4 & 2.15 \\
\hline Purpose of Loan & $\begin{array}{l}\text { Education of Their } \\
\text { Dependents }\end{array}$ & 26 & 13.97 \\
\cline { 2 - 4 } & $\begin{array}{l}\text { Household Consumptio } \\
\text { nd Improvement }\end{array}$ & 99 & 53.22 \\
\cline { 2 - 4 } & Acquire Assets & 28 & 15.05 \\
\cline { 2 - 4 } & Self-Employment & 22 & 11.82 \\
\cline { 2 - 4 } & Medical Treatment & 2 & 1.07 \\
\cline { 2 - 4 } & To Repay the Debts & 8 & 4.30 \\
\cline { 2 - 4 } & Others & 1 & 0.53 \\
\hline
\end{tabular}

About Impact of Joining Self Help Group $45 \%$ participant state the raise of income, $17 \%$ said Social Awareness or Participation, $14 \%$ gives the reason of Education of Dependents less than $9 \%$ of each describe it as Political Awareness or Participation Self Employment, self employment, Improved Nutrition in Household and others. The SHG members avail the loan facility mainly for the purpose of Household Consumption and Improvement (53\%), Acquire Assets (15\%), Education of Their Dependents (14\%), Self Employment (12\%), To Repay the Debts (4\%), Medical Treatment (1\%) and others $(0.5 \%)$.

As data of figure 2 represents the Decision Makers in Utilizing Loan Amount is manly spouse (53\%), very few decides by all $(21 \%)$, themselves $(18 \%)$ and by family $(8 \%)$.

\section{Decision Makers w.r.t. Utilizing Loan}

$\begin{array}{cccc} & 53 \% & & 21 \% \\ 18 \% & & 8 \% & \text { All }\end{array}$

Figure 2: Decision Makers in Utilizing Loan Amount

\section{DISCUSSION}

The study showed majority of the participants were 20-40 years age group i.e. $82.79 \%$, below 20 years were $4.84 \%$ and above 40 years were $11.83 \%$. Majority of the participants were having secondary education $37.63 \%$ followed by primary education $32.80 \%$ and the least were from graduation i.e. $1.07 \%$. This study shows the loan amount availed $69 \%$ of SHGs is above Rs 10000 and Rs. 3000 to Rs. 10000 by $18 \%$ of SHGs and below Rs 3000 by $13 \%$ of SHGs. This result is consistent with Nandini et al study which concluded $6.57 \%$ respondents have availed the loan of less than Rs 3000, 34.2\% respondents have availed the loan of Rs. 3000 to Rs. 10000 and the rest $59.21 \%$ respondents have availed the loan of more than Rs. 10000.

We describe the results of primary motive to join SHG which shows to develop saving $(63.30 \%)$ followed by getting credit facilities $(17.74 \%)$. These findings were in accordance with the findings reported by Shanty et al (2012) which showed the several reasons to join $\mathrm{SHG}$, the factor 'to add family income' had secured higher mean score. Anjugam et al in his study identified the reasons for joining SHG were getting loan from the group or bank; followed by promotion of incomegenerating activities were the major reasons for joining selfhelp groups. In line with previous studies (16) our result shows the period of functioning of SHGs is 1 to 3 year $(52.68 \%)$. From the result it is clear that $100 \%$ credit facilities is availed after joining SHGs and a similar conclusion was reached by Saravana (2016), a study done by secondary sources shows that record on the repayment of loans by women was often better than that of men, and that women were also more likely to spend the income earned, on their families, leading to improved health and nutrition of the poor population and for improving the quality of their lives. The results lead to a similar conclusion where Karamjeet Kaur (2016) in his study showed a positive impact of micro finance services on livelihood of people. Respondents strongly agreed with the fact that there was increase in the savings which leads to rise in income level, also in generating multiple income sources. Another study Saravanan (2016) also showed that Microfinance through SHG had become a ladder for the poor to bring them up not only economically but also socially, mentally and attitudinally and above all help them break through the stronghold of exploitative money lenders. This study showed that decision makers in utilizing loan amount in majority cases are spouse $53 \%$.The present study confirmed the findings about the purpose of getting a loan was for household consumption and improvement $(53.22 \%)$ followed by acquire assets $(15.05 \%)$ and education of their dependents (13.97\%). A study conducted in Odisha by Mahanty et al study concluded that major purposes for getting a loan was used to invest it in agriculture with mean value of 3.98 and was followed domestic consumption with mean value of 3.77. A proportion of credit was demanded by the SHG members for repayment of old debts. A less proportion of loan was demanded for education of their dependents.

\section{CONCLUSION}

Self Help Group is a significant tool which helps the rural women to empower themselves, not just for meeting their economic needs, but also more holistic social development for their self-supportive life. SHG Programme clearly plays a vital role in the lives of the poor. Also, microfinance plays a significant role in alleviate poverty and rural development. Microfinance to the rural SHGs is a way to improve the living standards and economic independence which further helps in 
gaining more self-confidence among the rural women. Additionally, it often presents as an achievement that forms the basis for social and economic improvements.

\section{ACKNOWLEDGEMENTS}

The authors would like to thank to all the study participants and the health workers of study area for their kind cooperation. Also thank to all the staff and colleagues for their necessary inputs.

\section{REFERENCE}

1. Naser, M. A., \& Crowther, D. (2016). Microfinance and women empowerment. Corporate Responsibility and Stakeholding, 49-65.

2. Saravanan, M. (2016). The impact of self-help groups on the socio-economic development of rural household women in Tamil Nadu-A study. International Journal of Research Vol. 4 No. 7 ISSN 2394, 3629, 22-31.

3. Sarumathi, S., \& Mohan, K. (2011). Role of Micro Finance in Women's Empowerment (An Empirical study in Pondicherry region rural SHG's). Journal of Management and Science, 1(1), 1-10.

4. Tehra, R. V. An Empirical Case Study of Women Self Help Group (SHG) functioning in Nanded City.

5. Saroj, L., \& Singh, C. (2015). Women Empowerment through Microfinance (SHGs): A Study of Ajmer District, Rajasthan, India. The Journal of Indian Management, 4(11), 1-6.

6. Carinne, B., Dworkin, S., Dunbar, M., Murthy, P., \&Pascoe, L. (2013). The effects of economic self-help group programs on women's empowerment: A systematic review. Campbell Systematic Reviews, 19.

7. Shanthi, M., \& Ganapathi, R. (2012). Impact of micro finance towards empowerment of women Self help groups with special reference to Coimbatore district. Prestige International Journal of Management \& IT-Sanchayan, 1(1), 67.

8. Sultana, H. Y., Jamal, M. A., \& Najaf, D. E. (2017). Impact of microfinance on women empowerment through poverty alleviation: An assessment of socioeconomic conditions in Chennai city of Tamil Nadu. Asian Journal for Poverty Studies (AJPS), 3(2).

9. Suja, S. (2012). WOMEN EMPOWERMENT THROUGH SELF-HELP GROUP-AN EVALUATIVE STUDY. Global Management Review, 6(3).

10. Reddy, K. R., \& Reddy, C. S. (2012). Self Help Groups in India. A Study on Quality and Sustainability. EnablePublication.

11. kumari Das, E., \& Baishya, D. (2015). Role of Self-
Help Groups in Empowering Rural Women: A case study on selected SHGs in Rani Block of Kamrup District of Assam. Journal of Economics and Finance, 6(2), 27-31.

12. Kodamatry, M. (2016). Microfinance and Women Empowerment: Self Perception of Beneficiaries-A study with reference to Gandhinagar District of Gujarat. Indiana Journal of research, 5(1).

13. Alam, P., \& Nizamuddin, S. (2012). Role of Micro Finance \& Self Help Groups in Women Empowerment: A Case Study of District Mewat. International Journal of Entrepreneurship \& Business Environment Perspectives, 1(2).

14. Anjugam, M., \& Ramasamy, C. (2007). Determinants of women's participation in self-help group (shg)-led microfinance programme in Tamil Nadu. Agricultural Economics Research Review, 20(347-2016-16640), 283-298.

15. Nilakantan, R. A. H. U. L., Datta, S. C., Sinha, P., \& Datta, S. K. (2013). The impact of microfinance on women empowerment: Evidence from Eastern India. International Journal of Development and Conflict, 3(1), 27-40.

16. Gupta, P. K., \& Hanagandi, S. S. (2012). A STUDY ON WOMEN EMPOWERMENT THROUGH SELF HELP GROUPS-WITH SPECIAL REFERENCE TO BIJAPUR DISTRICT, KARNATAKA. International Journal of Applied Financial Management Perspectives, 1(1), 66.

17. Kaur, N., \& Kaur, H. (2017). Microfinance and women empowerment. Vinimaya, 38(3), 30-49. 